\section{Agnieszka Wyrąbkiewicz}

Uniwersytet Mikołaja Kopernika, Toruń

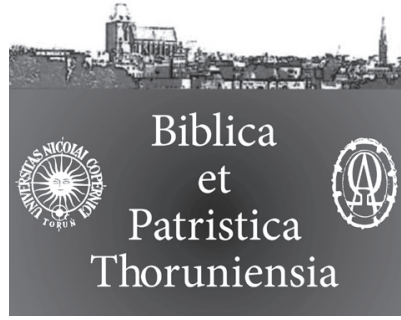

7 (2014) 3 ISSN 1689-5150

DOI: http://dx.doi.org/10.12775/BPTh.2014.017

\title{
Mistyczna teoria odkupienia w pismach św. Grzegorza z Nyssy
}

\section{The Mystical Theory of Redemption in the Writings of Gregory of Nyssa}

Słowa kluczowe: mistyka; natura ludzka; Wcielenie; przebóstwienie; uświęcenie; jedność; uczestnictwo w Bogu.

Keywords: mysticism; human nature; Incarnation; deification; Santification; unity; participation in God.

Streszczenie. Mistyczna teoria odkupienia św. Grzegorza z Nyssy koncentruje się wokół rozważenia tajemnicy Wcielenia jako włączenia przebóstwionej natury ludzkiej Jezusa Chrystusa w monadę ludzkości. Jedność ta stanowi formalną przyczynę współprzebóstwienia ludzkości i umożliwia naturze ludzkiej realizację jej pierwotnego powołania - naśladowania Osobowego Obrazu Bożego, objawionego we Wcielonym. Ofiarowane ludzkości obiektywne przebóstwienie, rozwijane przez Grzegorza w metaforyce pierwocin zakwaszających własną świętością ciasto natury ludzkiej, swą moc sprawczą czerpie z perychorezy natur Jezusa Chrystusa. Pośrednictwo Syna Bożego pozwala ludzkości odzyskać utracone przez grzech uczestnictwo w Bogu i stanowi ikonę jednolitej syntetycznej wizji historii zbawienia człowieka.

\begin{abstract}
The mystical theory of redemption in the writings of Gregory of Nyssa is concentrated on contemplating the mistery of Incarnation - inclusion of deificated human nature of Jesus Christ in the monad of humanity. This unity is the structural ground of co-deification of humanity and it enables human nature to achieve its initial mission-imitating the Personal Image of God, revealed in the Incarnated. The objective deification, donated humanity, elaborated by Gregory in the imagery of first fruits leavening with their own sanctity the cake of human nature, derives its causative power from perichoresis of Jesus Christ nature. Intercession of the Son of God enables humanity to regain participation in God, lost because of sin and it establishes the icon of a synthetic homogenous view of salvation of man.
\end{abstract}


$\mathrm{D}$ zięki nauczaniu o uczestnictwie wszystkich ludzki w jednej naturze św. Grzegorz z Nyssy, jako jeden z niewielu Ojców Wschodnich, bardzo mocno podkreśla powszechność grzechu pierworodnego ${ }^{1}$ tamującego realizację przebóstwienia „stworzonego na obraz i podobieństwo Boże” ( $\operatorname{Rdz} 1,26)$ człowieka. Dramat ten wyraźnie ukazuje deprawację istoty i życia ludzkiego, a w makroskali - całego gatunku ludzkiego (pleromy ${ }^{2}$ ) i otaczającego go świa$\mathrm{ta}^{3}$, lecz najgłębszy jego skutek wypełnia się w zamazaniu pierwowzoru pełni realizacji człowieczeństwa ${ }^{4}$, osiąganego na drodze nieustannego naśladowania „Obrazu Bożego” (Kol 1,15) $)^{5}$. Stąd w pismach Nysseńczyka spotykamy się $\mathrm{z}$ tak mocnym zaakcentowaniem momentu Wcielenia, otwierającego monadzie

1 Por. M. Przyszychowska, Nauka o łasce, s. 69. Nysseńczyk wskazując na fakt uczestnictwa wszystkich ludzi w jednej naturze stwierdza, że skutki grzechu, a zwłaszcza śmiertelność, przeszła na kolejne pokolenia ( $\tau \alpha \hat{\imath} \varsigma \tau \hat{\omega} \nu \tau \imath \kappa \tau o \mu \varepsilon \dot{\varepsilon} v \omega \nu \delta \imath \alpha \delta o \chi \alpha \hat{\imath} \varsigma$ ) - por. Gregorius Nyssenus, In Canticum canticorum, hom. XII, GNO 6, 351. Sam Nysseńczyk nigdy nie używa terminu grzech pierworodny, który w rozwoju doktryny pojawia się w późniejszym nauczaniu św. Augustyna z Hippony, niemniej opisując jego istotę i skutki, Grzegorz odwołuje się do jego rzeczywistości.

2 Termin pleroma (pełnia) w pismach Kapadocczyka w odniesieniu do ludzkości oznacza określoną liczbę istnień należących do wspólnej natury ludzkiej, utworzonej przy pierwszym aczasowym i niecielesnym akcie stwórczym, który Grzegorz rozwija w alegorycznej egzegezie Rdz 1, 27a, opierając się na koncepcji podwójnego stworzenia świata według wykładni Filona Aleksandryjskiego. Pozostając pod wpływem platońskiej doktryny o ideach, Grzegorz ujmuje ludzkość powołaną do bytu w pierwszym akcie stwórczym jako niepodzielną monadę, która nie może się pomnażać ani zmniejszać, lecz od razu powołana została przez Boga jako pełnia, stąd przychodzenie na świat nowych ludzi nie zwiększa jej sumy: „Natura zaś jest jedna, tworząca sama ze sobą jedność i jest całkowicie niepodzielną monadą, nie rosnącą przez dodanie, ani nie malejącą przez ubytek, lecz jest jako jedność i jako jedność pozostaje i ukazuje się w wielości, niepodzielna, trwała, nienaruszalna i nie dzieli się pomiędzy uczestniczących w niej” - Gregorius Nyssenus, Ad Ablabium, Quod non sint tres dei, GNO 3/1, 41, tłum. T. Grodecki: Grzegorz z Nyssy Drobne pisma trynitarne, s. 106. Por. także: M. Przyszychowska, przypis 74, w: Grzegorz z Nyssy, O stworzeniu człowieka, tłum. M. Przyszychowska, s. 98; W. Szczerba, A Bóg będzie, s. 259.

Choć starożytny Autor posługuje się terminem pleroma w wielorakim kontekście, m.in. dla wyrażenia pełni Bóstwa czy wspólnej natury Boga, w niniejszym artykule określenie to używane będzie wyłącznie do wyrażenia całościowo pojętej monady natury ludzkiej, utworzonej przez Nysseńczyka na wzór jednej istoty Boga.

3 Por. W. Szczerba, A Bóg będzie, s. 263.

4 Por. J. Wółkowski, A. Wyrąbkiewicz, Droga do szczęścia w nauczaniu Grzegorza $z$ Nyssy, w: Vita beata. Interpretacja szczęścia, s. 124-125.

5 Por. J. Naumowicz, Wstęp, w: Grzegorz z Nyssy, O naśladowaniu Boga, s. 26. 
ludzkiej drogę realizacji theosis ${ }^{6}$, dzięki rozbiciu jej zepsucia od wewnątrz przez rozświetlające misterium zjednoczenia się przebóstwionej natury ludzkiej Jezusa z całą pleromą. Ten bowiem, który ustanowiony został przyczyną wzorczą stworzenia człowieka, powołanego do bytu na wzór Obrazu Bożego, sam uniża się, by zejść z niewyrażalnej wielkości do niskości naszej naturyª

On zatem, który jest ponad wszelkim poznaniem i pojmowaniem, niewysłowiony (1 P 1,8), niewyrażalny i niewypowiedziany (2 Kor 9,15), z miłości do ludzi stał się obrazem Boga niewidzialnego. Wszystko po to, by ciebie ponownie uczynić swoim obrazem. Przyjął postać równą twojej, abyś dzięki Niemu mógł być znów ukształtowany na obraz pierwotnego piękna i byś w ten sposób stał się tym, czym byłeś na początku ${ }^{8}$.

Zwrotność aktu Wcielenia sprawia, że nie tylko ludzkość zostaje na nowo przywrócona na właściwe tory drogi ku pełni człowieczeństwa według pierwotnego zamysłu stwórczego ${ }^{9}$, lecz także sam Wcielony w przyjętej przez siebie naturze ludzkiej staje się obrazem według tego Obrazu Bożego, na wzór którego powstała ludzkość ${ }^{10}$. Dlatego też rozważenie problemu mistycznej teorii odkupienia, która, jak zaznacza Marta Przyszychowska, prowadzi do przekonania, że „Chrystus, łącząc się we Wcieleniu z całą ludzką naturą jako jednością, przez sam ten fakt ją przebóstwił"11, skoncentrowane zostanie wokół przedstawienia idei deifikacji ludzkiej natury Jezusa Chrystusa w aspekcie wewnętrznie zrealizowanego przebóstwienia we Wcielonym oraz otwarcia możliwości współprzebóstwienia ludzkości przez egzaltację Jego chwały na całą pleromę.

Podejmując się analizy problemu deifikacji ludzkiej natury Syna Bożego, warunek konieczny stanowi wyraźne określenie status quo zachodzącego pro-

6 Grzegorz nigdy nie używa rzeczownikowego określenia deifikacji. Sam proces przebóstwienia w jego pismach zilustrowany został za pomocą pełnych dynamiki zwrotów lub określeń czasownikowych, którymi starożytny Autor posługuje się z niezwykłą ostrożnością, aby nie dopuścić do naruszenia zasad ortodoksyjnej apofatycznej teologii wschodniej - por. D.L. Balás, Deification, w: The Brill Dictionary, s. 210-213.

7 Por. Gregorius Nyssenus, In Canticum canticorum, hom. XV, GNO 6, 436.

8 Gregorius Nyssenus, De perfectione, GNO 8/1, 195, tłum. J. Naumowicz: Grzegorz z Nyssy, O doskonałości 69, w: idem, O naśladowaniu Boga, s. 75.

9 Por. Gregorius Nyssenus, In Canticum canticorum, hom. IV, GNO 6, 126.

10 Por. S. Strękowski, Sofiologia św. Grzegorza z Nyssy, s. 172; E. Kotkowska, Nauczanie św. Grzegorza, s. 516-518; A. Wyrąbkiewicz, Nauka o przebóstwieniu człowieka, s. 244.

11 M. Przyszychowska, Wszyscy byliśmy w Adamie, s. 9. 
cesu. W całym dorobku mistycznego Autora ${ }^{12}$ przebóstwienie nigdy nie dotyczy deifikacji boskiej natury, która pozostając w perychorezie z człowieczeństwem Jezusa, odwiecznie i niezmiennie posiada boskość należącą do istoty Bytu Trójjedynego. Odnosząc zagadnienie przebóstwienia do procesu realizującego się w Synu Bożym należy zdecydowanie określić zakres owego terminu wyłącznie wobec, w pełni przyjętej przez Niego, kondycji ludzkiej, czego z całą stanowczością Nysseńczyk broni wobec błędów Eunomiusza w dziełach polemicznych Refutatio confessinis Eunomii czy Contra Eunomium oraz w traktacie dogmatycznym Ad Ablabium, Quod non sint tres dei. Tym samym studium poświęcone rozważeniu problemu deifikacji w Osobie Syna Bożego ma za zadanie wskazać kluczowe momenty nauczania św. Grzegorza traktujące o realizmie dokonania się theosis $\mathrm{w}$ antropologicznym aspekcie bytowania Jezusa ${ }^{13}$.

\section{Od Wcielenia do Zmartwychwstania - misteria przebóstwionej natury ludzkiej Jezusa}

W pismach Biskupa Nyssy zagadnienie przebóstwienia odnoszone wobec ludzkiej natury Syna Bożego łączy się z głębokim namysłem nad tajemnicą Wcielenia, lecz ostatecznie moment ten nie stanowi jego kulminacji, ponieważ proces deifikacji obejmuje całościowo pojęte misterium Jezusa Chrystusa. Według E. Kotkowskiej odkupienie rodzaju ludzkiego kreślone w dziełach Kapadocczyka obejmuje trzy etapy: od odnowienia obrazu Bożego dokonanego w momencie Wcielenia, które w niniejszym artykule pogłębione zostanie $\mathrm{w}$ aspekcie wewnętrznie zrealizowanego przebóstwienia natury ludzkiej Chrystusa, przez etap poddania normalnemu biegowi zamazanej przez grzech egzystencji ludzkiej w akcie ekspiacji Jezusa na krzyżu, aż po egzaltację chwały Zmartwychwstałego przy wniebowstąpieniu ${ }^{14}$. Podejmując się rozważenia mistycznej, personalistycznej teorii odkupienia, którą Grzegorz rozwija za Irene-

12 O mistycyzmie Grzegorza zob. J. Daniélou, Platonisme et théologie mistique, s. 6; F. Drączkowski, Grzegorz z Nyssy, w: Encyklopedia katolicka, t. VI, 316-320; R. Tichy, Tajemnicza natura Grzegorza z Nyssy, s. 441-459; E. Kotkowska, Pomyśleć świat, s. 13; P. Szczur, „Święć się Imię Twoje” w wykładzie, s. 296.

13 Por. W. Szczerba, A Bóg będzie, s. 222-223; K. Corrigan, Evagrius and Gregory, s. 179, przypis 20; S. Strękowski, Sofiologia św. Grzegorza, s. 136; J. Rother, Gottverähnlichung als, s. 508.

14 Por. E. Kotkowska, Pomyśleć świat, s. 64, 162-176; eadem, Nauczanie św. Grzegorza, s. 513. Zob. także S. Strękowski, Wcielenie Syna Bożego, s. 199. 
uszem, Orygenesem i Bazylim Wielkim ${ }^{15}$, warto skupić się przede wszystkim na dwóch zbawczych wydarzeniach - Wcieleniu i Zmartwychwstaniu, które wśród żyjących w IV w. przedstawicieli wspomnianej teorii, poczynając od Atanazego Wielkiego, zostają szczególnie zaakcentowane ${ }^{16}$. Uwzględniając przy tym fakt, że podjęta od Ireneusza doktryna rekapitulacji, stanowiąca podstawę wczesnochrześcijańskiej refleksji o jedności natury ludzkiej, dochodzi u Nysseńczyka do swego punktu szczytowego ${ }^{17}$, nie budzi wątpliwości wymienienie Grzegorza wśród najbardziej reprezentatywnych głosicieli mistycznej (bądź fizycznej) teorii odkupienia. Teoria ta, której rys charakterystyczny J.N.D. Kelly widzi w ścisłej tendencji do łączenia się z platońską doktryną realizmu pojęć ogólnych, traktującej ludzką naturę jako jedną całość rodzajową ${ }^{18}$, u Nysseńczyka wybrzmiewa w sposób niezwykle wyraźny i przekonujący, co również znajduje swe odzwierciedlenie $\mathrm{w}$ zainteresowaniu omawianym zagadnieniem wśród grona badaczy (m.in. H.U. von Balthasar, J. Gross, J.R. Bouchet, L. Malavez, D.L. Balás, M. Przyszychowska $\left.{ }^{19}\right)$.

\section{2. „Stający się obraz" - objawienie przebóstwionej natury ludzkiej Jezusa}

Etap pierwszy, dokonujący się w przyjęciu przez Syna Bożego ludzkiej natury stanowi początek odnowy rodzaju ludzkiego, w którym Wcielony „ze względu na nas wszedł w dzisiaj, zstąpił z przedwiecznego i niezmiennego majestatu i narodził się w czasie"20. Tym samym Syn posiadający równą Ojcu naturę, będąc pełnym i doskonałym Obrazem Bożym, poddaje się, by stać się takim, jak stworzenie - obrazem według tego Obrazu, na wzór którego stworzony został człowiek $^{21}$ :

15 Por. J. Rother, Gottverähnlichung als, s. 526; S. Strękowski, Sofiologia św. Grzegorza, s. 184.

16 Por. J.N.D. Kelly, Początki doktryny, s. 281.

17 Por. M. Przyszychowska, Wszyscy byliśmy w Adamie, s. 160.

18 Por. J.N.D. Kelly, Początki doktryny, s. 280.

19 H.U. von Balthasar, Présence et Pensée; J. Gross, La divinisation du chrétien; J.R. Bouchet, La vision de l'économie, s. 613-644; L. Malavez, L'Église dans le Christ, s. 257-281; D.L. Balás, The Unity of Human, s. 275-281; M. Przyszychowska, Nauka o łasce.

20 Gregorius Nyssenus, In inscriptiones Psalmorum, GNO 5, 102, tłum. M. Przyszychowska: Grzegorz z Nyssy, O tytułach psalmów, s. 76.

21 Por. E. Kotkowska, Nauczanie św. Grzegorza, s. 516. 
W Chrystusie jest coś stworzonego i coś niestworzonego; częścią niestworzoną jest Jego nieśmiertelne i odwieczne istnienie oraz stwarzanie wszystkich bytów, częścią śmiertelną zaś część ukształtowana na wzór naszego poniżonego ciała ze względu na Boży zamysł względem nas. [...] Mam na myśli wielką tajemnicę pobożności, przez którą Bóg ukazał się w ciele, Ten, który był w postaci Boga i który pod postacią sługi przebywał w ciele wśród ludzi. On, gdy przez pierwociny pociągnął ku sobie śmiertelną cielesną naturę, przyjętą dzięki nieskalanemu dziewictwu, nieustannie poprzez te pierwociny uświęca całe ciasto natury, bo przez tych, którzy są z Nim zjednoczeni we wspólnocie misterium, karmi swoje ciało, czyli Kościół, i dzięki wierze odpowiednio łączy ze wspólnym ciałem wrośnięte w siebie członki oraz porządkuje wszystko, czyniąc $\mathrm{z}$ wierzących odpowiednio i harmonijnie oczy, usta, ręce i pozostałe członki ${ }^{22}$.

Owa zwrotność ikonicznego charakteru natury ludzkiej Syna Bożego ukazana w misterium Wcielenia wskazuje na wewnętrzną polaryzację dwóch prawd: zjednoczenia się Chrystusa z ludzką monadą oraz przywrócenia widzialnego Pierwowzoru, umożliwiającego ludzkości powrót do pierwotnego stanu jedności ze Stwórcą ${ }^{23}$. Powodowany filantropią wobec ludzkości Syn ${ }^{24}$, jednorodzony Bóg, będący przyczyną stworzenia wszystkiego ${ }^{25}$, staje się człowiekiem i włącza $w$ siebie całą ludzkość, jednocząc ją z Ojcem ${ }^{26}$. Wcielenie będące wejściem Boga w realną jedność natury ludzkiej ${ }^{27}$, którą konsekwentnie Grzegorz przedstawia w analogii do jedności natury Boskiej, stanowi podstawę zbawienia natury ludzkiej per se, dzięki uświęceniu dokonującemu się poprzez unię hipostatyczną z naturą Boską ${ }^{28}$. Stąd przedstawienie natury ludzkiej jako

22 Gregorius Nyssenus, In Canticum canticorum, hom. XI, GNO 6, 380-382, tłum. M. Przyszychowska: Grzegorz z Nyssy, Homilie do Pieśni nad Pieśniami, s. 197-198.

23 Por. Gregorius Nyssenus, In Canticum canticorum, hom. IV, GNO 6, 126. Tym samym Nysseńczyk inspirujący się ideą niewidzialnego Obrazu Pierwowzoru zastanego w nauczaniu Ireneusza, Atanazego oraz Marcelego z Ancyry, w oryginalny sposób przedstawia Chrystusa w momencie Wcielenia, ukazując Go jako stający się obraz. Dzięki temu, zatarty w ludzkości obraz Boży odnajduje swoją pełnię, przez co może ona powrócić do pierwotnego stanu odbijania boskiego elementu wpisanego w jej prawdziwą naturę. Por. S. Strękowski, Sofiologia św. Grzegorza, s. 172; L.F. Mateo Seco, Obrazy obrazu, s. 369.

24 Por. Gregorius Nyssenus, In inscriptiones Psalmorum, GNO 5, 131-32, tłum. M. Przyszychowska: Grzegorz z Nyssy, O tytułach psalmów, s. 94.

25 Por. ibidem, GNO 5, 107, tłum. M. Przyszychowska: Grzegorz z Nyssy, O tytułach psalmów, s. 79.

26 Por. E. Kotkowska, Pomyśleć świat, s. 165.

27 Por. Gregorius Nyssenus, Antirrheticus aduersus Apollinarium, GNO 3/1, 151. Zob. M. Przyszychowska, Wszyscy byliśmy w Adamie, s. 82.

28 Por. W. Szczerba, Problem przebóstwienia, s. 287. 
jedna ov̉oí $\alpha^{29}$, która w definicji natury Osób Boskich w traktacie Ad Ablabium, Quod non sint tres dei Boga zostaje przez Nysseńczyka zaakcentowana w wymiarze jedności i niepodzielności boskiej ov̉ $\sigma^{\prime} \alpha^{30}$, stanowi również wzór jedności gatunku ludzkiego ${ }^{31}$. Co więcej, dzięki takiemu zestawieniu Grzegorz wyraźnie podkreśla, że „Natura Boga, choć niedostępna stworzeniu, znajduje w Chrystusie doskonałą egzemplifikację w świecie człowieka. Paradoksalnie Bóg wcielony staje się dla człowieka obrazem Boga, a - ujmując problem w kategoriach teleologicznych - wcielony Logos staje się pierwocinami ( $\alpha \pi \alpha \rho \chi \grave{\eta})$ przebóstwionego człowieczeństwa i najdoskonalszym wyznacznikiem drogi powrotu dla ludzkości”32. Chrystus zostaje więc przedstawiony jako pełnia człowieczeństwa i to człowieczeństwa przebóstwionego, która dzięki perychorezie z boskością stanowi niejako rozświetlenie upadłej po grzechu ludzkiej natury, ukazując prawdziwe powołanie pleromy. Dokonujący się wewnątrz ludzkiej natury Chrystusa proces doskonałej deifikacji stanowi podstawę do mówienia o obiektywnej deifikacji całej ludzkości, podjęcia zbawczej inicjatywy ze strony Boga, który uniżając samego siebie wywyższa człowieczeństwo do pierwotnych ram z Rdz 1,26:

Bóg, który uczynił wszystko w mądrości, lecząc jej brzydotę, nie stwarza w niej jakiegoś nowego piękna, którego wcześniej nie było, ale prowadzi ją do pierwotnej łaski, gdy dzięki przetapianiu tej, którą zło uczyniło czarną, czyni ją nieskażoną ${ }^{33}$.

29 Por. Gregorius Nyssenus, De hominis opificio, PG 44, 185.

30 Por. Gregorius Nyssenus, Ad Ablabium, Quod non sint tres dei, GNO 3/1, 41, tłum. T. Grodecki: Grzegorz z Nyssy, Drobne pisma trynitarne, s. 106; K. Corrigan, Evagrius and Gregory, s. 179-180.

Zagadnienie analogii istniejącej pomiędzy naturą boską i naturą ludzką znajduje swoją kontynuację w dialogu $O$ duszy $i$ zmartwychwstaniu, w którym Nysseńczyk stwierdza, że to, co nie odnosi się do Boga, nie może znajdować się także w definicji duszy człowieka (Por. Gregorius Nyssenus, De anima et resurrectione, PG 46, 49). Ponadto charakterystycznym rysem Grzegorzowego nauczania o podobieństwie natur stanowi wskazanie, że boski wzór, obraz Boży, wpisany jest nie tyle w pojedynczego człowieka, lecz całą ludzkość (Por. Gregorius Nyssenus, De hominis opificio, PG 44, 187). Autor przestrzega jednak, że skoro stanowi on odbicie niepoznawalnego Boga, sam również nie może zostać w pełni poznany (Por. Gregorius Nyssenus, De hominis opificio, PG 44, 156; 184).

31 Por. M. Przyszychowska, Wszyscy byliśmy w Adamie, s. 60.

32 W. Szczerba, Problem przebóstwienia, s. 289. Zob. także. J. Zachhuber, Human nature, s. 191.

33 Gregorius Nyssenus, In Canticum canticorum, hom. IV, GNO 6, 101, tłum. M. Przyszychowska: Grzegorz z Nyssy, Homilie do Pieśni nad Pieśniami, s. 67. 
lub:

Stworzenie świata jest bowiem [jednocześnie] powstaniem Kościoła, w którym, zgodnie ze słowami proroka, powstaje nowe niebo [...] i inny człowiek, odnowiony

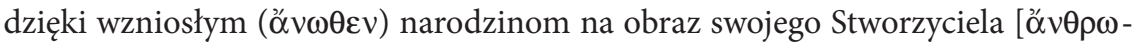

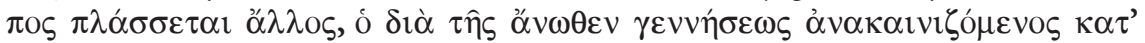

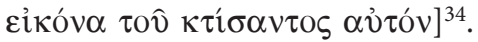

Przenosząc nauczenie wczesnochrześcijańskiego Kościoła Wschodniego o zbawczej wymianie przebóstwienia człowieka dzięki Wcieleniu Boga, Grzegorz włącza wypracowaną przez siebie koncepcję zjednoczenia się Wcielonego z całą ludzkością w duchowe doświadczenie miłosnej relacji bohaterów Homilii do Pieśni nad pieśniami. Jako mistyk w prawdach wiary dostrzega życiową drogę wierzącego, stąd tak częste w pismach duchowych Kapadocczyka przeniesienie ich treści do opisu bezpośredniej relacji człowieka wznoszącego swą duszę ku Bogu. Taki zabieg pozwala Grzegorzowi jeszcze dobitniej podkreślić misterium Wcielenia Jezusa, które, ujęte w mistyczne terminy, wyraża niepojętą miłość Boga, a więc przyczynę Jego zejścia ku człowiekowi i zjednoczenia się z całą ludzkością. Moment ten w sposób metaforyczny Grzegorz określa mianem łoże ( $\kappa \lambda i ́ v \eta)$, co pozwala mu uchwycić w prostym obrazie intymność zjednoczenia obu natur:

Łożem (w sensie metaforycznym) nazywa Oblubienica złączenie natury ludzkiej

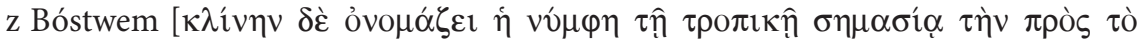

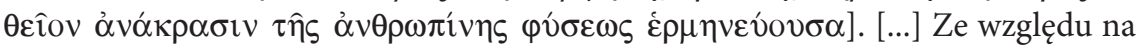

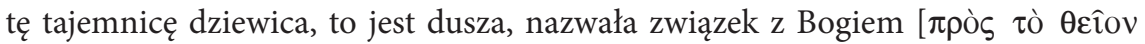

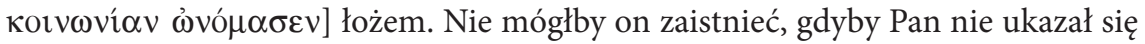
nam zacieniony ciałem ${ }^{35}$.

W przybraniu przez Syna Bożego natury ludzkiej Nysseńczyk dostrzega również aspekt epistemiczny - poznania Obrazu Bożego, stanowiącego właściwą miarę człowieczeństwa. Chrystus, jako Pośrednik łączący w sobie naturę boską i naturę ludzką, staje się jedyną drogą poznania niedostępnego Boga, przy jednoczesnym zachowaniu apofatycznego charakteru doktryn Wschodnich, głoszących niemożliwość poznania natury Boskiej. Przybranie ciała staje się niezbędnym warunkiem, okryciem niedostępnej boskości, aby człowiek

34 Ibidem, hom. XI, GNO 6, 384-385, tłum. M. Przyszychowska: Grzegorz z Nyssy, Homilie do Pieśni nad Pieśniami, s. 199-200.

35 Ibidem, hom. IV, GNO 6, 108-109, tłum. M. Przyszychowska: Grzegorz z Nyssy, Homilie do Pieśni nad Pieśniami, s. 70. 
mógł wejść w Jego pośrednictwo i na nowo kierować się ku swemu powołaniu - zjednoczeniu z Bogiem:

Przyszedłeś - mówi bowiem - ty: piękny, umiłowany, pełen blasku i stałeś się zacieniony przy naszym łożu. Gdybyś bowiem nie zacienił samego siebie, zakrywając czysty płomień Bóstwa postacią sługi, któż mógłby znieść twój widok? Nikt nie może zobaczyć Boga i przeżyć. Przyszedłeś zatem ty, który jesteś pełen blasku, lecz stałeś się takim, byśmy mogli cię przyjąć: przyszedłeś, zacieniwszy promień Bóstwa przykryciem z ciała. Jak mogłaby śmiertelna i zniszczalna natura złączyć się z naturą czystą i niedostępną, gdyby cień ciała nie stał się pośrednikiem między światłem a nami, żyjącymi w ciemności? ${ }^{36}$

Dzięki mocnemu podkreśleniu prawdy wiary o przyjęciu przez Jezusa we wcieleniu cielesnego, materialnego ciała, Nysseńczyk inspirujący się ideą niewidzialnego Obrazu Pierwowzoru, zastanej w nauczaniu Ireneusza, Atanazego oraz Marcelego z Ancyry, w oryginalny sposób przedstawia Chrystusa w momencie inkarnacji jako ujawniający się obraz ${ }^{37}$. Co więcej, zatarty przez grzech Adama obraz Boży w Chrystusie wcielonym odnajduje swoją pełnię przez co ludzkość może powrócić do pierwotnego stanu odbijania boskiego elementu wpisanego w jej prawdziwą naturę ${ }^{38}$ i rozwijać pokrewieństwo, które wskazywać ma na jedność deifikacji ludzkości i człowieczeństwa Jezusa, dokonującą się przez przyjęcie całej pleromy w ludzkiej naturze Syna Bożego. Obraz ten zostaje w pismach Biskupa z Nyssy podkreślony także poprzez ukazanie Chrystusa jako podnoszące ludzkość pierwociny przebóstwionego człowieczeństwa, które powoli traci cechy upadłej rasy i nabiera cech boskości ${ }^{39}$.

\section{Tajemnica obdarowania pleromy darem współprzebóstwienia}

Wyjaśniając sposób oddziaływania Wcielenia wobec tajemnicy zjednoczenia i odnowy rodzaju ludzkiego Grzegorz stosuje liczne analogie ${ }^{40}$, wśród któ-

36 Ibidem, hom. IV, GNO 6, 107-108, tłum. M. Przyszychowska: Grzegorz z Nyssy, Homilie do Pieśni nad Pieśniami, s. 70.

37 Por. S. Strękowski, Sofiologia św. Grzegorza, s. 172.

38 Por. L.F. Mateo Seco, Obrazy obrazu, s. 369.

39 Por. B.E. Daley, Divine Transcendence, s. 89.

40 Uzupełniając zagadnienie metaforyki rozwiniętej przez Kapadocczyka w celu określenia sposobu oddziaływania Wcielonego na monadę ludzką, warto wspomnieć także o komplementarnym porównaniu wyrażającym jedność ludzkości w obrazie owcy: „Ten, który przybył, aby ożywić i ocalić to, co zginęło, a to właśnie pasterz nazywa w przypowieści 
rych najbardziej kluczową stanowi metafora ciasta, którego Chrystus, wraz z przyjęciem człowieczeństwa, staje się zaczynem ${ }^{41}$. Obraz ten przywołany zostaje w kontekście przebóstwienia wspólnej Jezusowi i całej ludzkości natury, o czym Nysseńczyk najwyraźniej mówi w dwóch krótkich fragmentach wykładu katechizmowego Oratio catechetica ${ }^{42}$ oraz apologetycznym dziele Antirrheticus aduersus Apollinarium ${ }^{43}$ i stanowi nawiązanie do Pawłowego stwierdzenia

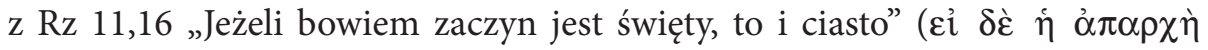

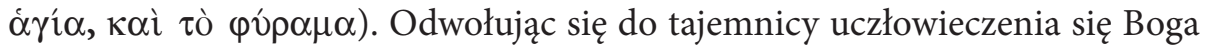
poprzez przyjęcie ludzkiej natury, Grzegorz wskazuje na wspólnotę łaski, która promieniując z przebóstwionej ludzkiej natury Jezusa Chrystusa, dzięki pokrewieństwu i wspólnemu pochodzeniu ${ }^{44}$, współprzebóstwia i uświęca w boską jedność całą monadę:

Słowo, które było na początku u Boga, które z miłości do ludzi, stając się ciałem przez wspólnotę z naszą słabą naturą, po to zmieszało się z człowiekiem i przyjęło na siebie całą naszą naturę, aby przez zmieszanie z Bóstwem przebóstwić ludzkość

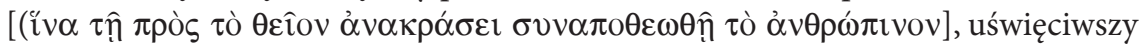
dzięki owym pierwocinom całe ciasto naszej natury ${ }^{45}$.

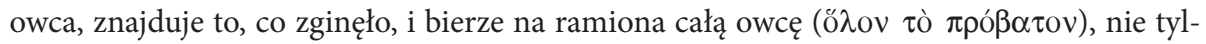

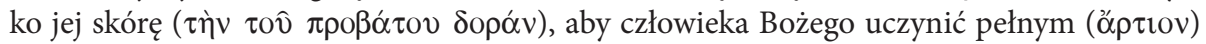

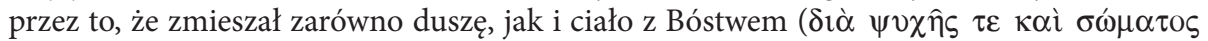

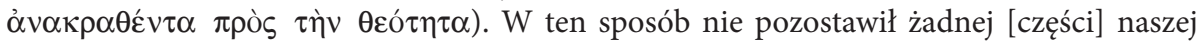

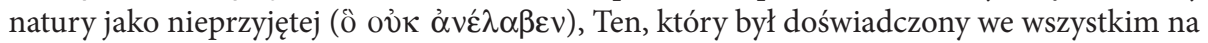
[nasze] podobieństwo, z wyjątkiem grzechu" - Refutatio confessionis Eunomii 175, tłum. M. Przyszychowska: eadem, Nauka o łasce, s. 83. Kategoria ta podkreśla jedność ludzkości pojętej na wzór jednego organizmu, która stanowi podstawę fizycznej teorii przebóstwienia. Co więcej, w obrazie tym Grzegorz równocześnie uwydatnia indywidualność natury ludzkiej Chrystusa i przyjęcia przez Logos natury ludzkiej jako takiej, a więc całej ludzkości. Tym samym złączenie się z całą monadą Wcielonego oznacza przebóstwienie jej całej: „To my, ludzka natura, będziemy tą owcą, którą ocalił dobry pasterz" - Contra Eunomium III, 2, 49, tłum. M. Przyszychowska: eadem, Nauka o łasce, s. 86.

41 Por. Gregorius Nyssenus, Oratio catechetica 35; idem, Antirrheticus aduersus Apollinarium, GNO 3/1, 151.

42 Oratio catechetica 35 i 37.

43 GNO 3/1, 151.

44 Por. Gregorius Nyssenus, Oratio catechetica 35, tłum. T. Sinko: Grzegorz z Nyssy, Wybór pism, s. 120.

45 Gregorius Nyssenus, Antirrheticus aduersus Apollinarium, GNO 3/1, 151, tłum. M. Przyszychowska: eadem, Nauka o łasce, s. 34. 


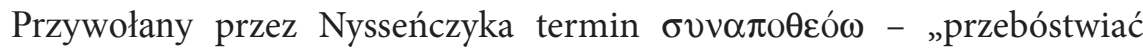
z sobą”, „wespół ubóstwiać”, „współprzebóstwiać”, wyraża zjednoczenie ludzkości w akcie Wcielenia z przebóstwioną naturą ludzką Jezusa, stąd w pismach Grzegorza termin ten stanowi najistotniejsze narzędzie językowe, poprzez które Autor najmocniej podkreśla w swoim nauczaniu doktrynę theosis. W całej spuściźnie Biskupa Nyssy czasownik ten występuje trzykrotnie - dwukrotnie by wyrazić włączenie ludzkości w przebóstwienie obiektywne darowane w akcie Wcielenia, dopełnione w egzaltacji chwały Zmartwychwstania ${ }^{46}$, jednokrotnie - aby opisać skutki sakramentalnego przyjmowania Ciała i Krwi Pańskiej na człowieka wierzącego ${ }^{47}$. Warto jednak podkreślić, że Grzegorz nigdy nie podaje detalicznego opisu procesu włączenia całej pleromy w misterium przebóstwienia natury ludzkiej Syna Bożego, jednak z głębokim przekonaniem podkreśla istniejącą pomiędzy nimi łączność, jako przyczynę warunkującą włączenie ludzkości w egzaltację boskości w tajemnicy Wcielenia i Zmartwychwstania ${ }^{48}$. Dzięki temu ofiarowane nam zostało obiektywne współprzebóstwienie, które równocześnie wyznacza drogę odwzorowania go w indywidualnej egzystencji każdego człowieka, włączającego się przez życie sakramentalne w misteria Chrystusa, aż do przebóstwienia wszystkich jednostek pleromy:

Ponieważ więc i ten składnik otrzymało ciało, mające przyjąć Boga, do swej budowy, a objawione Słowo dlatego zmieszało się z podległą zniszczeniu naturą ludzką, aby przez wspólność z boskością ubóstwiło się zarazem człowieczeństwo [ò $\delta \grave{\varepsilon}$

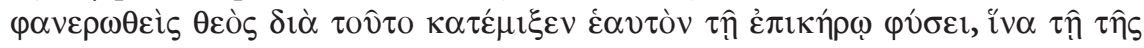

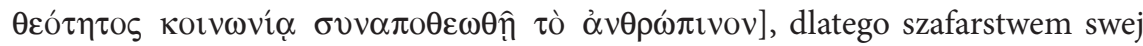
łaski wsiewa się niejako przez ciało wszystkim wierzącym, wmieszany w ich ciała, zawierające wino i chleb, aby przez zjednoczenie z pierwiastkiem nieśmiertelności także człowiek stał się uczestnikiem nieśmiertelności. To zaś daje natura widzialnego chleba i wina, przemieniona mocą błogosławieństwa na Jego ciało i krew ${ }^{49}$.

46 Oratio catechetica 35; Antirrheticus aduersus Apollinarium, GNO 3/1, 151. Por. D.L. Balás, Deification, s. 212; A. Wyrąbkiewicz, Nauka o przebóstwieniu, s. 246.

47 Gregorius Nyssenus, Oratio catechetica 37. Por. D.L. Balás, Deification, s. 212; A. Wyrąbkiewicz, Nauka o przebóstwieniu, s. 247.

48 Por. D.L. Balás, Deification, s. 210-211.

49 Gregorius Nyssenus, Oratio catechetica 37, tłum. T. Sinko: Grzegorz z Nyssy, Wybór pism, s. 129. Według M. Przyszychowskiej fragment „Słowo dlatego zmieszało się z podległą zniszczeniu naturą ludzką, aby przez wspólność z boskością ubóstwiło się zarazem człowie-

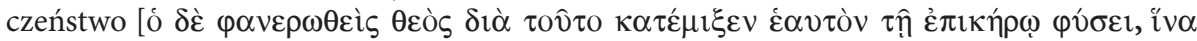

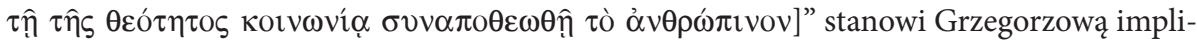
kację maksymy św. Atanazego skupiającej w sobie złotą regułę soteriologii patrystycznej:

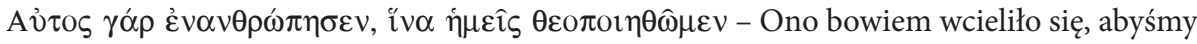
my zostali przebóstwieni. Por. Athanasius Alexandrinu, De incarnatione Verbi Dei, 54, 3, PG 
$\mathrm{Na}$ postawie tak pojętego uczestnictwa ludzkości w uwielbieniu Jezusa, Grzegorz odnosi termin $\sigma v v \alpha \pi o \theta \varepsilon ́ \omega$ do deifikacji człowieka, łącząc ją właśnie ze współwyniesieniem dokonującym się w przebóstwionej naturze ludzkiej Syna Bożego, co jeszcze dobitniej podkreśla we wcześniejszym fragmencie Oratio catechetica:

jako że rzeczywiście zdziałał życie i zarazem ubóstwione, wspólnie zbawia to,

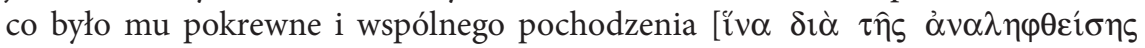

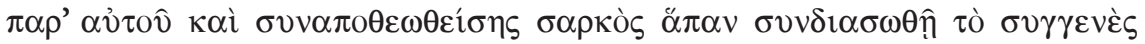

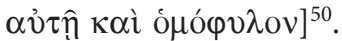

Mówiąc o przebóstwieniu człowieczeństwa Chrystusa, w konsekwencji Nysseńczyk zauważa także, że cała ludzkość jest jakoś współdeifikowana. Nie dzieje się to na zasadzie deifikacji wszystkich cech albo wszystkich elementów ludzkiej natury, lecz uczestnictwa jednostek we wspólnej naturze ludzkiejej, co wskazuje również na kluczową rolę jaką w procesie przebóstwienia człowieka Grzegorz przyznawał tajemnicy inkarnacji - rozbicia monady ludzkiej od wewnątrz i wejścia w nią zaczynu świętości. Dlatego też, jak zauważa M. Przyszychowska, w pismach Nysseńczyka obraz powrotu ludzkiej natury do początku znajduje swoją przyczynę sprawdzą nie tyle dzięki Wcieleniu, ile wręcz we Wcieleniu ${ }^{52}$ :

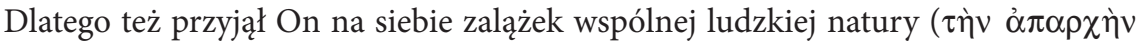

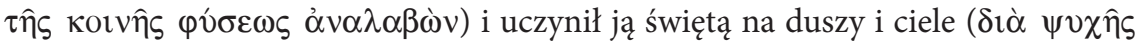

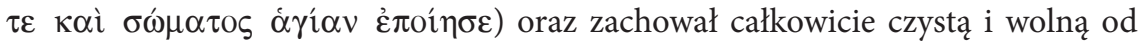
domieszki zła. Uczynił to, by ten zalążek, pozostały w nieskazitelności przedstawić nieskazitelnemu Ojcu. Dzięki tym pierwocinom mógł przyciągnąć wszystko, co

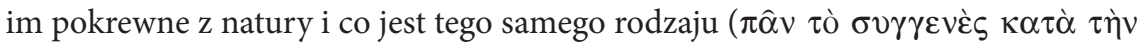

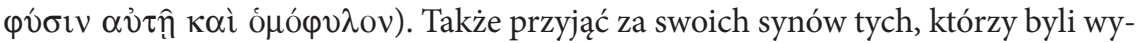

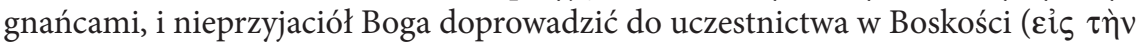
$\tau \hat{\eta} \varsigma \theta \varepsilon o ́ \tau \eta \tau o \varsigma ~ \alpha \bigcup ̉ \tau o \hat{~} \mu \varepsilon \tau o v \sigma i ́ \alpha v)^{53}$.

25, 192B; M. Przyszychowska, Nauka o łasce, s. 87-88. Zob. też: J. Naumowicz, Wcielenie Boga, s. 17.

50 Gregorius Nyssenus, Oratio catechetica 35, tłum. T. Sinko: Grzegorz z Nyssy, Wybór pism, s. 120.

51 Por D.L. Balás, Deification, s. 212.

52 Por. M. Przyszychowska, Nauka o łasce, s. 87.

53 Gregorius Nyssenus, De perfectione christiana, GNO 8/1, 206, tłum. J. Naumowicz: Grzegorz z Nyssy, O naśladowaniu Boga, s. 82. 
Powyższe nauki Biskupa Nyssy skupiają się wokół rozważenia tajemnicy oddziaływania przebóstwionej natury ludzkiej Jezusa na całą pleromę, stąd badacze myśli Grzegorza nie kwestionują zjednoczenia Słowa z całą ludzką naturą, mimo iż wyodrębniają dwa sposoby rozumienia owego połączenia: czy to dzięki przyjęciu przez Wcielonego ludzkiej natury jako całości, czy też dzięki przyjęciu konkretnej ludzkiej natury stanowiącej w jakiś sposób jedność z całością ${ }^{54}$. L. Malavez, podkreślający przenikającą pisma Nysseńczyka ideę przyjęcia przez Jezusa konkretnej natury ludzkiej, w powyższych stwierdzeniach przyznaje, że nie da się tutaj rozumieć ludzkiej natury inaczej niż w sensie zbiorowym $^{55}$. Zdanie to odzwierciedla główny temat zainteresowania Grzegorza - realną jedność ludzkości, która mimo częstego przywoływania w spuściźnie Autora, nie zostaje rozważona pod kątem sposobu uczestnictwa jednostek w naturze ludzkiej ${ }^{56}$, co znajduje swe przełożenie na brak detalicznego rozważenia uczestnictwa konkretnej natury ludzkiej Chrystusa w pleromie:

Poświęca Bogu i Ojcu nie tylko pierworodne dzieci, ale całe ludzkie plemię ( $\pi \hat{\alpha} v$

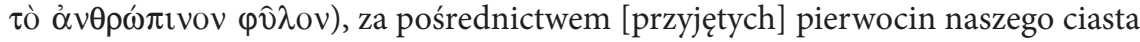

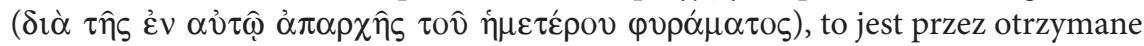

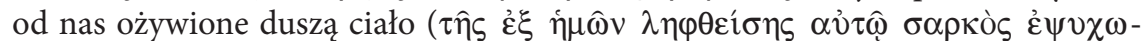

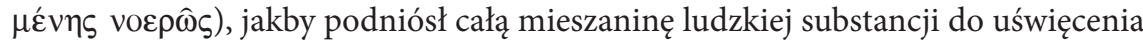

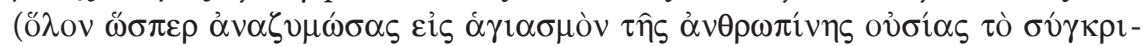
$\mu \alpha$ ). Jeśli bowiem pierwociny [są] święte - mógłbym powiedzieć i ja za Boskim Apostołem - to i ciasto ${ }^{57}$.

Alegoria pierwocin staje się więc najmocniejszym obrazem, w którym Kapadocczyk wyjaśnia wizję jedności natury ludzkiej i opisuje relację Chrystusa $\mathrm{z}$ tą naturą ${ }^{58}$. Stanowiąc formalną przyczynę zaczątku przemiany stworzenia od wewnątrz ${ }^{59}$ ludzka natura Chrystusa staje się zaczynem biorącym na siebie

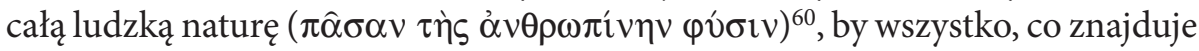

\footnotetext{
54 Por. M. Przyszychowska, Nauka o łasce, s. 82.

55 Por. L. Malavez, L'Église dans le Christ, s. 269.

56 Por. M. Przyszychowska, Wszyscy byliśmy w Adamie, s. 82.

57 Gregorius Nyssenus, De occursu Domini, PG 53, 1165, tłum. M. Przyszychowska: eadem, Nauka o łasce, s. 82-83.

58 Por. M. Przyszychowska, Nauka o łasce, s. 83.

59 Por. E. Kotkowska, Nauczanie św. Grzegorza, s. 521.

60 Por. In Canticum canticorum, hom. XIV, GNO 6, 427-428, tłum. M. Przyszychowska: Grzegorz z Nyssy, Homilie do Pieśni nad pieśniami, s. 220: „a Pan, który dzięki pierwo-

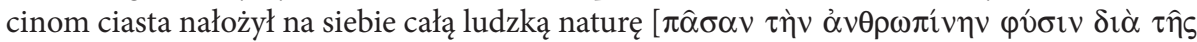

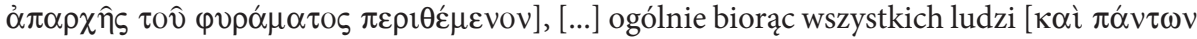


się w jednym gatunku, przyciągnąć do tego samego rodzaju ${ }^{61}$. Jednocześnie jest to akt, w którym Jezus uświęca całą naturę ludzką ${ }^{62}$, ponieważ Jego człowieczeństwo jako pierwsze dostąpiło pełni przebóstwienia:

W sobie zjednoczył On z mocą bóstwa swą ludzką naturę, która stanowi część wspólnej natury ludzkiej, chociaż nie podlega jej namiętnością, jakie pobudzają do grzechu ${ }^{63}$.

\section{Misterium przebóstwienia ludzkiej natury Jezusa}

Człowieczeństwo przyjęte przez Syna Bożego w momencie Wcielenia stanowi początek odnowy całego rodzaju ludzkiego, ponieważ przebóstwiona ludzka natura jak zaczyn wlewa się w całą monadę, zakwaszając pleromę. Siła sprawcza współprzebóstwienia ludzkości, pochodząca z natury ludzkiej Jezusa, znajduje swą moc w tajemniczej perychorezie $\mathrm{z}$ naturą boską. W ten sposób oryginalnie utworzona koncepcja przebóstwienia człowieka kreślona w dziełach Nysseńczyka przedstawia Chrystusa świętego jako Boga, zaś jako człowieka świętego przez uczestnictwo ${ }^{64}$. To ważne zastrzeżenie starożytnego Autora ściśle określa granice procesu deifikacji, która, choć przynależy antropologicznemu bytowaniu Jezusa natychmiastowo od momentu inkarnacji, swą podstawę znajduje w boskości, będącej doskonałym katalizatorem dopełniającym przebóstwienia ludzkiej natury Jezusa w jednym akcie. Rozróżnienie to pozwala głębiej zrozumieć pośredniczą rolę Chrystusa, który dzięki swej konkretnej ludzkiej naturze staje się pomostem pomiędzy Bogiem a pleroma:

Dlatego Pośrednik między Bogiem i ludźmi, przyjąwszy pierwociny całej ludzkiej

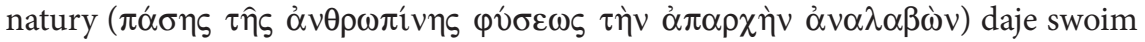

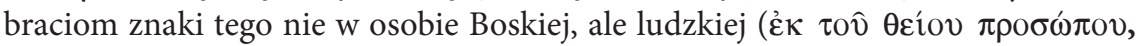

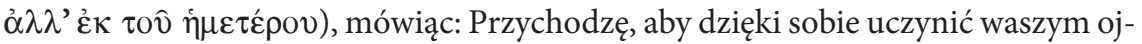
cem Tego, który prawdziwie jest Ojcem, od którego się oddaliliście, i uczynić dzięki

ő $\pi \alpha \xi \not ̉ v \theta \rho \omega ́ \pi \omega v$ ], Ten ze swoim ciałem, które [symbolizuje] osioł, zatrzymał się w miejscu poniżenia człowieka, opatrzywszy rany wsadził go na swoje zwierzę i uczynił ze swojej miłości gospodę dla niego, w której odpoczywają wszyscy utrudzeni i obciążeni”.

61 Por. Grzegorz z Nyssy, O doskonałości 71, tłum. J. Naumowicz: Grzegorz z Nyssy, O naśladowaniu Boga, s. 82.

62 Por. In Canticum canticorum, hom. XIII, GNO 6, 381.

63 Grzegorz z Nyssy, O doskonałości 69, tłum. J. Naumowicz: Grzegorz z Nyssy, O naśladowaniu Boga, s. 81.

64 Por. S. Strękowski, Wcielenie Syna, s. 206. 
sobie waszym Bogiem prawdziwego Boga, od którego odstąpiliście: przez pierwo-

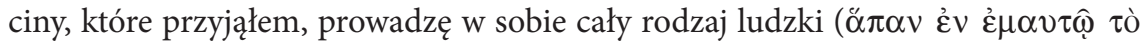

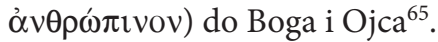

Pośrednictwo Jezusa wypełnia się więc w przywróceniu możliwości osiągnięcia przez ludzkość stanu uczestnictwa w Bogu, a tajemnicza perychoreza natur Chrystusa ilustruje realizującą się jednolitą syntetyczną wizję historii zbawienia człowieka ${ }^{66}$ :

[Bóg] zmieszał się z naszą naturą, by ta stała się Boska dzięki przymieszaniu Bo-

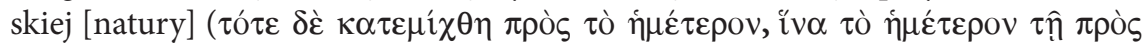

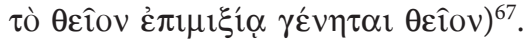

Jak zauważa W. Szczerba, w ujęciu tym zbawienie w sensie strukturalnym jest aktem dokonanym - natura ludzka jako całość znajduje się w stanie przebóstwiona, dzięki czemu dzieło zbawienia physis zostało dopełnione ${ }^{68}$. Tym samym nawiązując do Atanazjańskiej formuły zbawczej wymiany ujętej w kategorii przebóstwienia, Grzegorz ujmuje Wcielenie jako istotny moment dokonania obiektywnej deifikacji - przez zjednoczenie się Chrystusa z ludzką naturą, następuje także jej przebóstwienie ${ }^{69}$. Ten wielki dar, wynoszący upadłego człowieka, dokona się w pełni jednak dopiero wtedy, gdy wszyscy poszczególni nosiciele natury ludzkiej zostaną przeniknięci łaską i utworzą ciało Chrystu$\mathrm{sa}^{70}$. Dlatego też możliwość subiektywnej deifikacji wyznaczona zostaje przez Filozofa z Nyssy jako zbawcza współpraca człowieka z darem wysłużonym przez Chrystusa, odpowiedź wiary na ofiarowany przez Boga dar uświęcających pierwocin:

Twierdzimy, że jednorodzony Bóg stwarza wszystko i rządzi wszystkim, a jedną ze stworzonym przez Niego rzeczywistości jest ludzka natura, która zwróciwszy się ku złu i zaznawszy przez to zepsucia śmierci, została dzięki Niemu przywrócona

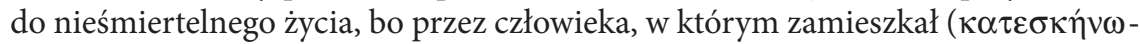

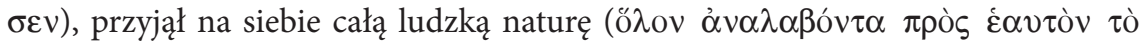

65 Gregorius Nyssenus, Refutatio confessionis Eunomii 83, tłum. M. Przyszychowska: eadem, Nauka o łasce, s. 83.

66 Por. G.A. Maloney, Chrystus Kosmiczny, s. 134.

67 Gregorius Nyssenus, Oratio catechetica 25, tłum. M. Przyszychowska: eadem, Nauka o łasce, s. 88.

68 Por. W. Szczerba, Problem przebóstwienia, s. 287.

69 Por. M. Przyszychowska, Nauka o łasce, s. 87.

70 Por. L. Boros, Odkrywanie myśli, s. 82. 


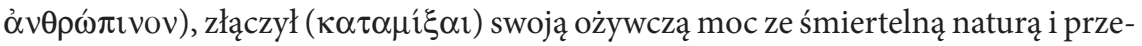
mienił naszą śmiertelność w łaskę i moc przez domieszanie jej do siebie samego

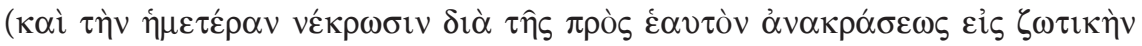

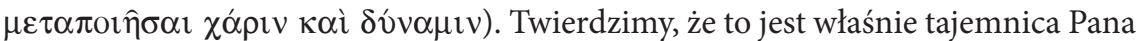

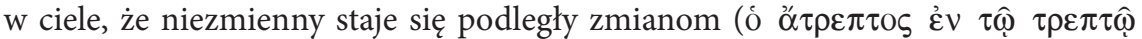

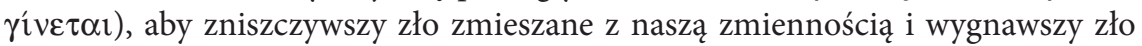

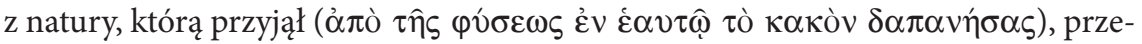
mienić z gorszego w lepsze. Bóg nasz jest bowiem ogniem oczyszczającym, który trawi wszelką miarę $\mathrm{zła}^{71}$.

Zdaniem E. Kotkowskiej stan przebóstwienia człowieka wypełnia się w rosnącej zdolności do przyjęcia miłości Ojca, jako najdoskonalszego sposobu poddania się stworzenia panowaniu Boga, ponieważ natura ludzka mimo jedności z Nim nigdy nie stanie się boską, a Chrystus, choć zjednoczył w sobie cały rodzaj ludzki, po swoim zmartwychwstaniu nie przyjął go do unii hipostatycznej ${ }^{72}$. Stąd podejmowana przez poszczególne jednostki gatunku ludzkiego przemiana na wzór żywego Obrazu Bożego, Figury przez którą cała ludzkość może uczestniczyć $\mathrm{w}$ procesie przebóstwienia ${ }^{73}$, stanowić ma współpracę z Bożą łaską, dzięki której człowiek przewyższa własną naturę ${ }^{74}$. Dlatego też według H.U. von Balthasara, wybitnego badacza myśli Nysseńczyka, to właśnie na bazie nieustannego transcendowania swojego człowieczeństwa bazuje cała mistyka starożytnego Autora ${ }^{75}$, w których spotkać się możemy z najpełniej zaprezentowanymi schematami dynamicznej wędrówki ludzkości ku Bogu.

\section{Podsumowanie}

Św. Grzegorz z Nyssy należy do najwybitniejszych przedstawicieli patrystycznej mistycznej teorii odkupienia, którą oparł na dwóch komplementarnych obrazach: realnej jedności natury ludzkiej oraz jej rozbicia od wewnątrz przez rozświetlające upadłą naturę Wcielenie. Moment ten zdaniem Nysseńczyka stanowi akt przebóstwienia całej natury ludzkiej, przyjętej przez Syna Bożego, aby jako zaczyn uświęcić całe ciasto ludzkości. Współprzebóstwienie ofiarowane

71 Gregorius Nyssenus, Contra Eunomium III, 3, 51-52, tłum. M. Przyszychowska: eadem, Nauka o łasce, s. 87.

72 Por. E. Kotkowska, Pomyśleć świat, s. 167.

73 Por. B.E. Daley, Divine Transcendence, s. 94

74 Por. Grzegorz z Nyssy, O celu życia i prawdziwej ascezie 95, tłum. J. Naumowicz: Grzegorz z Nyssy, O naśladowaniu Boga, s. 129.

75 Por. H.U. von Balthasar, Presence and Thought, s. 38. 
ludzkości, czerpiące swą moc sprawczą z tajemniczej perychorezy natur boskiej i ludzkiej Chrystusa, jest wyrazem egzaltacji chwały Wcielonego, który z niepojętej miłości do człowieka wychodzi z odwieczności ku zmienności bytu ludzkiego, objawiając zamazany przez grzech Adama Obraz Boży. Równocześnie dynamika Wcielenia - poddania się Jezusa, by stać się na obraz Boży - zostaje przez Grzegorza ukazana jako doskonała egzemplifikacja niedostępnej stworzeniu natury Boskiej.

Ramy mistycznej teorii odkupienia kreślonej w spuściźnie Nysseńczyka łączą protologię z eschatologią, a jej punkt centralny wypełnia się w wejściu w doczesność pierwocin uświęcenia - Jezusa Chrystusa. I choć Grzegorzowa koncepcja przebóstwienia posiada charakterystyczne pęknięcie, wyznaczone przez zarysowującą się $\mathrm{w}$ jego pismach swoistą biegunowość powiązania daru obiektywnej deifikacji - dokonanej w przebóstwionej, objawiającej się we Wcieleniu naturze ludzkiej Jezusa Chrystusa i wolnego podjęcia mającej się zrealizować w indywidualnym życiu jednostek ludzkich deifikacji subiektywnej, stanowi spójny system ukierunkowany ku podkreśleniu jedności całego rodzaju ludzkiego oraz soteriologicznych implikacji misterium Syna Bożego.

Oryginalnie utworzona koncepcja przebóstwienia człowieka kreślona w dziełach Nysseńczyka przedstawia Chrystusa świętego jako Boga, zaś jako człowieka świętego przez uczestnictwo w Boskości. To ważne zastrzeżenie starożytnego Autora wskazuje na ścisłe granice procesu deifikacji, która, choć przynależy antropologicznej egzystencji Jezusa od momentu inkarnacji, swą podstawę znajduje w boskości - doskonałym katalizatorze przebóstwienia ludzkiej natury Jezusa, dokonującej się natychmiastowo w akcie złączenia obu natur we Wcieleniu.

\section{Bibliografia}

Gregorius Nyssenus, Ad Ablabium, Quod non sint tres dei, w: idem, Opera dogmatica minora, ed. F. Mueller, E.J. Brill, Gregorii Nysseni Opera 3/1, Leiden 1958.

Gregorius Nyssenus, Antirrheticus aduersus Apollinarium, w: idem, Opera dogmatica minora, ed. F. Mueller, E.J. Brill, GNO 3/1, Leiden 1958.

Gregorius Nyssenus, De hominis opificio, H. Hörner (ed.), Gregorii Nysseni Opera, Leiden 1972.

Gregorius Nyssenus, De perfectione, w: tenże, Opera ascetica, ed. W. Jaeger, Gregorii Nysseni Opera 8/1, Leiden 1963.

Gregorius Nyssenus, In Canticum canticorum, ed. H. Langerbeck, Gregorii Nysseni Opera 6, Leiden 1960.

Gregorius Nyssenus, In inscriptiones Psalmorum, ed. J. Donough, Gregorii Nysseni Opera 5, Leiden 1962, s. 24-175. 
Grzegorz z Nyssy, Nauka katechetyczna, w: tenże, Wybór pism, tłum. T. Sinko, Warszawa 1963 , s. 57-136.

Gregorius Nyssenus, Oratio catechetica, ed. E. Mühlenberg, GNO 3/4, Leiden 1996.

Grzegorz z Nyssy, O stworzeniu człowieka, tłum. M. Przyszychowska, Źródła Myśli Teologicznej 39, Kraków 2006.

Grzegorz z Nyssy, O tym, że nie można mówić, że jest trzech Bogów - Do Abliusza, w: tenże, Wybór pism, tłum. T. Grodecki, Źródła Myśli Teologicznej 21, Kraków 2001, s. 104-117.

Grzegorz z Nyssy, O tytułach Psalmów, tłum. M. Przyszychowska, Źródła Myśli Teologicznej 72, Kraków 2014.

Balás D.L., Christian Transformation of Greek Philosophy Illustrated by Gregory of Nyssa's Use of the Notion of Participatuion, „Proceedings of the American Catholic Philosophical Association" 40 (1966), s. 152-157.

Balás D.L., Deification, w: The Brill Dictionary of Gregory of Nyssa, red. L.F. Mateo-Seco, G. Maspero, "VigCh Supplements" 99 (2010), s. 210-213.

Balás D.L., $\mu \varepsilon \tau o v \sigma i ́ \alpha$ $\theta \varepsilon o v$. Man's Participation in God's Perfections According to Saint Gregory of Nyssa, „Studia Anselmiana” 55, Rome 1966.

Balás D.L., The Unity of Human Nature in Basil's and Gregory of Nyssa's Polemics against Eunomius, „Studia Patristica” 14, s. 275-281.

Balthasar H.U. von, Présence et Pensée. Essai sur la philosophie religieuse de Grégoire de Nysse, Paris 1988.

Balthasar H.U. von, Presence and Thought. An Essay on the Religious Philosophy of Gregory of Nyssa, tr. M. Sebanc, I. Press, San Francisco 1995.

Boros L., Odkrywanie myśli, przekł. C. Tarnogórski, Warszawa 2000.

Bouchet J.R., La vision de léconomie du salut selon Grégoire de Nysse, „Recherches des Sciences Philosophiques et Theologiques" 52 (1968), s. 613-644.

Corrigan K., Evagrius and Gregory. Mind, soul and body in the 4th century, "Ashgate Studies in Philosophy \& Theology in Late Antiquity", Ashgate 2009.

Daley B.E., Divine Transcendence and Human Transformation: Gregory of Nyssa's AntiApollinarian Christology, „Studia Patristica” 32/4, s. 87-95.

Daley B.E., 'Heavenly Man' and 'Eternal Christ': Apollinarius and Gregory of Nyssa on the Personal Identity of the Savior, „Journal of Early Christian Studies” 10/4 (2002) 469-488.

Daniélou J., Platonisme et théologie mistique, Essai sur la doctrine spirituelle de saint Grégoire de Nysse, Paris 1944.

Drączkowski F., Grzegorz z Nyssy, w: Encyklopedia katolicka, t. VI, s. 316-320.

Eckmann A., Przebóstwienie człowieka w pismach wczesnochrześcijańskich, Lublin 2003.

Gross J., La divinisation du chrétien d'après les Pères Grecs. Contribution historique a la doctrine de la grâce, Paris 1938.

Kelly J.N.D., Początki doktryny chrześcijańskiej, Warszawa 1988.

Kotkowska E., Nauczanie św. Grzegorza z Nyssy o wszechmocy Bożej na podstawie In illud: Tunc ipse Filius, „Vox Patrum” 24 (2004) 46-47, s. 511-526.

Kotkowska E., Pomyśleć świat jako całość według św. Grzegorza z Nyssy, Poznań 2003. 
Malavez L., L'Église dans le Christ. Êtude de théorique historique et théorique, „Recherches de Science Religieuse" 25 (1935) 3, s. 257-281.

Maloney G.A., Chrystus Kosmiczny. Od Pawła do Teilharda, przekł. T. Mieszkowski, Warszawa 1986.

Mateo Seco L.F., Obrazy obrazu (Rodzaju 1, 26 i Kolosan 1, 15 u św. Grzegorza z Nyssy), VoxP 26 (2006) 49, s. 367-382.

Naumowicz J., Wcielenie Boga i zbawienie człowieka. Złota reguła soteriologii patrystyc$z n e j$, „Warszawskie Studia Teologiczne” 13 (2000), s. 17-30.

Naumowicz J., Wstęp, w: Grzegorz z Nyssy, O naśladowaniu Boga. Pisma ascetyczne. Co znaczy być chrześcijaninem. O doskonałości. O celu życia i prawdziwej ascezie, przekł. i oprac. J. Naumowicz, Kraków 2011, s. 7-43.

Przyszychowska M., Nauka o łasce w dziełach świętego Grzegorza z Nyssy, Kraków 2010.

Przyszychowska M., Wszyscy byliśmy w Adamie. Jedność ludzkości w Adamie w nauczaniu ojców Kościoła, Poznań 2013.

Rother J., Gottverähnlichung als ein Weg zur Gotteinigung beim hl. Gregor von Nyssa [Diss. Innsbruck 1934], w: ed. H.R. Drobner, A. Viciano, Gregory of Nyssa. Homilies on the Beatitudes, "VigCh Supplements" 52 (2000), s. 507-568.

Russell N., The doctrine of deification in the Greek patristic tradition, Oxford 2006.

Strękowski S., Sofiologia św. Grzegorza z Nyssy. Elementy teologii trynitarnej i antropologii w „Homiliach do Pieśni nad Pieśniami”, Kraków 2006.

Strękowski S., Wcielenie Syna Bożego w utworach św. Grzegorza z Nyssy, „Vox Patrum” 20 (2000) 38-39, s. 199-212.

Szczerba W., A Bóg będzie wszystkim we wszystkim... Apokatastaza Grzegorza z Nyssy: tło, źródła, kształt koncepcji, Kraków 2008.

Szczerba W., Problem przebóstwienia na tle apofatycznej teologii Grzegorza z Nyssy, „Filozofia religii” 5 (2009) 283-299.

Szczur P., „Święć się Imię Twoje” w wykładzie św. Grzegorza z Nyssy, red. J. Misiurek, J.M. Popławski, K. Burski, „Homo Orans” t. 5, Lublin 2004, s. 293-304.

Tichy R., Tajemnicza natura Grzegorza z Nyssy (Poczet mistyków chrześcijańskich), „Fronda” 13/14 (1998), s. 441-459.

Wółkowski J., Wyrąbkiewicz A., Droga do szczęścia w nauczaniu Grzegorza z Nyssy, w: Vita beata. Interpretacja szczesścia ludzkiego w starożytności chrześcijańskiej, red. D. Zagórski, Toruń 2011, s. 115-127.

Wyrąbkiewicz A., Nauka o przebóstwieniu człowieka w świetle Wielkiej mowy katechetycznej Grzegorza z Nyssy, „Biblica et Patristica Thoruniensia” 6 (2013), s. 239-248 .

Zachhuber J., Human nature in Gregory of Nyssa, Philosophical Background and Theological Significance, Leiden 2000. 